\title{
Association between Irritable Bowel Syndrome and Allergic Diseases: To Make a Case for Aeroallergen
}

\author{
Evelyn Xiu Ling Loo ${ }^{a, b}$ De Yun Wang ${ }^{c}$ Kewin Tien Ho Siah ${ }^{d, e}$ \\ a Singapore Institute for Clinical Sciences, Agency for Science, Technology and Research, Singapore, Singapore; \\ ${ }^{b}$ Department of Pediatrics, Yong Loo School of Medicine, National University of Singapore, Singapore, Singapore; \\ 'Department of Otolaryngology, Yong Loo Lin School of Medicine, National University of Singapore, Singapore, \\ Singapore; ${ }^{d}$ Division of Gastroenterology and Hepatology, University Medicine Cluster, National University

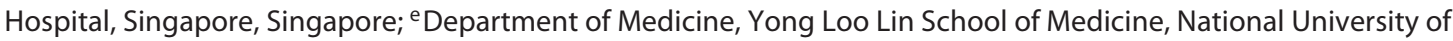 \\ Singapore, Singapore, Singapore
}

\section{Keywords}

Irritable bowel syndrome · Allergic diseases · Aeroallergens

\begin{abstract}
Irritable bowel syndrome (IBS) is a functional gastrointestinal disease and the most common cause of prolonged abdominal pain and bowel disturbances in the developed world. While initially thought to be functional or psychosomatic in nature, IBS is now recognized as a heterogeneous group of conditions. A subset of IBS patients and patients with allergic diseases share some characteristic inflammatory features. In fact, atopic children show an increased likelihood of developing IBS as adults. Given these findings, a subset of IBS may be suffering from allergy-related gut diseases. In this review, we present the allergy-related comorbidities of IBS, including genetic, environmental, and immunologic factors. We discuss studies demonstrating an increased sensitization of IBS patients to aeroallergens compared to food allergens. We then postulate potential pathophysiological mechanisms underlying both IBS and aeroallergens in the gut, followed by potential implications in the screening and treatment of allergies in IBS patients.

(c) 2019 S. Karger AG, Basel
\end{abstract}

\section{Introduction}

Irritable bowel syndrome (IBS) is a multifactorial gastrointestinal disorder affecting $5.2-22 \%$ of the population [1]. It is not a single disease, but a name given to a group of gastrointestinal symptoms that commonly present together. IBS is diagnosed according to symptom-based criteria (e.g., Manning criteria to ROME IV criteria). While these criteria have changed over time, the essential feature remains unchanged: recurrent and intermittent abdominal pain or discomfort that is associated with irregular bowel habits [2]. IBS likely represents a diverse group of disorders with a similar presentation but different pathophysiologies, such as post-infectious mucosal inflammation, food intolerance, hypersensitivity, or allergic disease. In fact, there is an increased prevalence of IBS in people with allergic diseases, suggesting a possible link between the two diseases $[3,4]$.

Allergy or atopy is an immediate hypersensitivity, or type I hypersensitivity reaction, caused by the release of

Edited by: H.-U. Simon, Bern.

\section{KARGER}

(c) 2019 S. Karger AG, Basel

E-Mail karger@karger.com

www.karger.com/iaa
Dr. Kewin Tien Ho Siah

Division of Gastroenterology and Hepatology

1E, level 10, Kent Ridge Road

Singapore 119228 (Singapore)

E-Mail kewin_siah@ nuhs.edu.sg 
mediators from mast cells. This release is often triggered by the binding of an immunoglobulin E (IgE) antibody (specific to an environmental antigen) to mast cells in various tissues. Allergic diseases range in severity, from life-threatening anaphylactic reactions to a certain food or insect bite to recurrent asthma, allergic rhinitis (AR), and atopic dermatitis (AD). The diagnosis of an allergic disease depends on the identification of allergen-related symptoms and the relevant allergen-specific IgE [5].

Mucosal immune activation and inflammation may contribute to the development of IBS. IBS may involve a mast cell-mediated inflammatory reaction [6] that affects epithelial cells. In turn, this would affect the epithelial barrier's permeability, causing inflammation [7]. In 2008, Tobin et al. [8] proposed the term "atopic IBS" to describe a novel subgroup of IBS associated with allergic diseases. They reported that the prevalence of IBS, compared to the general population, was significantly higher in patients with $\mathrm{AR}$ (2.67 times) and $\mathrm{AD}$ (3.20 times). In this review, we present relevant epidemiological and clinical studies that link IBS and allergic diseases as well as postulate the possible mechanisms linking the two diseases.

\section{Epidemiology}

\section{IBS and Asthma}

Asthma is a chronic respiratory disease characterized by recurrent airway inflammation, obstruction, and hyperresponsiveness. There are multiple epidemiological studies that show asthma and IBS often co-exist in a single patient (Table 1; Fig. 1). A link between IBS and asthma was first suggested by White et al. [9]. They observed that IBS patients, like asthmatic patients, show increased respiratory hyperresponsiveness - as measured by forced expiratory volumes in $1 \mathrm{~s}$ after inhalation of increasing concentrations of methacholine. Similar findings were made by Kennedy et al. [10], who showed that IBS, gastroesophageal reflux symptoms, and bronchial hyper-responsiveness occurred more frequently together than expected $(2.5 \%$ of the sample having all 3 conditions compared with an expected prevalence of $0.7 \%)$. Another large study with 91,237 asthmatic subjects and 24,518 non-asthmatic subjects, found a $20 \%$ increase in the likelihood of asthmatic subjects developing IBS following their initial diagnosis with asthma. The development of IBS following a diagnosis of asthma was not associated with the use of oral steroids [11]. Similarly, Roussos et al. [12] observed an increased prevalence of IBS among asthmatic patients compared to subjects with other pulmo- nary disorders ( 41.3 vs. $22.3 \%)$ and showed again that asthma medications were not associated with the development of IBS. In another study from the United Kingdom that reviewed medical records of 23,471 patients from primary care practices across the country, an increased prevalence of atopy in patients with functional gastrointestinal disorders (FGIDs) was found. The association between FGIDs and atopic conditions remained statistically significant even after controlling for demographic factors and mood disorders [13]. Cohen et al. [14] reviewed the medical records of 314,897 consecutive 17-year-old males, undergoing comprehensive medical evaluation prior to recruitment for military service in Israel. Again, IBS was significantly more prevalent in asthmatics compared to non-asthmatics ( 1 vs. $0.5 \%$ ); IBS was also significantly more prevalent in subjects with persistent asthma compared to those with intermittent asthma $(p<0.001)$. There was no difference observed between asthmatic and non-asthmatic and the incidence of inflammatory bowel disease (IBD) or peptic ulcers.

Asthma has also been associated with childhood-onset FGIDs. In an Italian study including 75 children with bronchial asthma and age- and sex-matched controls, asthmatic children showed a significantly greater frequency of gastrointestinal symptoms, particularly diarrhea, vomiting, and abdominal pain [15]. Colman et al. [16] in the United States showed a high prevalence of FGIDs (16.4\%) among young patients (4-20 years old) with persistent asthma. Similarly, the BAMSE (Swedish abbreviation for Children, Allergy, Milieu, Stockholm, Epidemiology) study found that asthma and food hypersensitivity in the first 2 years of life were significantly associated with the development of abdominal pain at 12 years of age. BAMSE study also found a direct relationship between a 12-year-old's risk for abdominal pain and the number of allergic conditions they had (i.e., asthma, rhinitis, eczema, and food allergy) [17]. Another study found the prevalence of IBS to be significantly higher among young asthmatics compared to elderly asthmatics and healthy, age-matched controls [18]. Several pathogenic mechanisms may explain the observed relationship between IBS and asthma, including an age-related decrease in the number of neurons in the myenteric plexus, increase in collagen deposition in the distal colon, and age-related perceptual changes $[19,20]$.

In contrast, several studies have shown no association between allergic diseases and IBS. Two cross-sectional studies found no association between asthma and IBS in teenagers/adolescents [21] and adults [22]. Results from the Dunedin Multidisciplinary Health and Develop-
Loo/Wang/Siah 
Table 1. Epidemiological study of IBS and asthma

\begin{tabular}{|c|c|c|c|c|c|c|c|c|}
\hline \multirow{2}{*}{$\begin{array}{l}\text { Author, } \\
\text { country }\end{array}$} & \multirow[t]{2}{*}{ Number } & & \multirow[t]{2}{*}{ IBS criteria } & \multicolumn{2}{|l|}{$\%$ IBS } & \multirow[t]{2}{*}{ OR (95\% CI) } & \multirow[t]{2}{*}{$p$ value } & \multirow[t]{2}{*}{ Note } \\
\hline & & & & non-asthma & asthma & & & \\
\hline $\begin{array}{l}\text { Huerta et al. } \\
{[106], \mathrm{UK}}\end{array}$ & 479 & Prospective & $\begin{array}{l}\text { Doctor } \\
\text { diagnosis }\end{array}$ & 2.0 & 2.5 & $1.3(1.1-1.5)$ & & $\begin{array}{l}\text { Risk of IBS could be reduced by } \\
\text { the use of oral steroids }\end{array}$ \\
\hline $\begin{array}{l}\text { Roussos et al. } \\
{[12], \text { Greece }}\end{array}$ & 400 & Prospective & ROME II & 20.8 & 41.3 & & 0.001 & $\begin{array}{l}\text { None of the asthma } \\
\text { medications were associated } \\
\text { with increased or decreased } \\
\text { likelihood of IBS }\end{array}$ \\
\hline $\begin{array}{l}\text { Amra et al. [107], } \\
\text { Iran }\end{array}$ & 4,762 & Prospective & ROME II & 3.3 & 9.5 & $1.79(1.06-3.03)$ & & $\begin{array}{l}\text { No relation between IBS and } \\
\text { chronic bronchitis }\end{array}$ \\
\hline $\begin{array}{l}\text { Cole et al. } \\
{[11], \text { USA }}\end{array}$ & 115,775 & Retrospective & $\begin{array}{l}\text { Doctor } \\
\text { diagnosis }\end{array}$ & 6.8 & 9.7 & $1.4(1.3-1.6)$ & & $\begin{array}{l}\text { No association with oral } \\
\text { steroids }\end{array}$ \\
\hline $\begin{array}{l}\text { Ekici et al. } \\
{[18], \text { Turkey }}\end{array}$ & 131 & & & 16.8 & 27.5 & $1.8(1.0-3.4)$ & 0.04 & $\begin{array}{l}\text { Young asthmatic but not old } \\
\text { asthmatic }\end{array}$ \\
\hline $\begin{array}{l}\text { Ozol et al. } \\
{[43], \text { Turkey }}\end{array}$ & 220 & Prospective & ROME II & 12.7 & 29.6 & & $<0.005$ & No relation with food allergy \\
\hline $\begin{array}{l}\text { Panicker et al. } \\
\text { [108], Kuwait }\end{array}$ & 283 & Prospective & ROME II & 7.93 & 39.13 & & $<0.001$ & $\begin{array}{l}\text { Female }>\text { male asthmatics; } \\
\text { Bloating and diarrhea were the } \\
\text { most common IBS symptoms }\end{array}$ \\
\hline $\begin{array}{l}\text { Yilmaz et al. } \\
\text { [109], Turkey }\end{array}$ & 168 & Prospective & ROME II & 17.9 & 36.6 & & 0.009 & $\begin{array}{l}\text { Not associated with psychiatric } \\
\text { disorders }\end{array}$ \\
\hline $\begin{array}{l}\text { Jones et al. } \\
\text { [13], USA }\end{array}$ & 23,471 & Retrospective & GP codes & 11.0 & 15.0 & $1.40(1.29-1.52)$ & 0.0001 & \\
\hline $\begin{array}{l}\text { Siddiqui et al. } \\
\text { [22], India }\end{array}$ & 140 & Prospective & ROME II & 20.00 & 17.14 & $0.828(0.320-2.121)$ & 0.664 & Negative study \\
\hline $\begin{array}{l}\text { Koloski et al. } \\
\text { [62], Australia }\end{array}$ & 3,542 & $\begin{array}{l}\text { Prospective, } \\
\text { postal survey }\end{array}$ & $\begin{array}{l}\text { Modified } \\
\text { ROME III }\end{array}$ & 12.1 & 20.0 & $1.82(1.44-2.30)$ & $<0.001$ & $\begin{array}{l}\text { Only IBS-C and IBS-M. A } \\
\text { pollen allergy was also } \\
\text { significantly associated with IBS } \\
\text { including IBS-D and PI-IBS but } \\
\text { not IBS-C or IBS-M; There was } \\
\text { a substantial moderate } \\
\text { significant effect size of } 4.68 \text { for } \\
\text { pollen allergy in PI IBS; a self- } \\
\text { reported animal allergy was } \\
\text { significantly associated with IBS, } \\
\text { IBS-M, and PI-IBS but not } \\
\text { IBS-C or IBS-D }\end{array}$ \\
\hline $\begin{array}{l}\text { Nybacka et al. } \\
{[24], \text { Sweden }}\end{array}$ & 270 & Prospective & ROME III & 9 & 18 & & 0.19 & Negative study \\
\hline $\begin{array}{l}\text { Cohen et al. } \\
\text { [14], Israel }\end{array}$ & 314,897 & $\begin{array}{l}\text { Medical } \\
\text { record review }\end{array}$ & $\begin{array}{l}\text { Doctor } \\
\text { diagnosis }\end{array}$ & 0.5 & 1 & $1.2(1.14-1.32)$ & 0.001 & $\begin{array}{l}\text { All } 17 \text {-year-olds, IBS } \\
\text { significantly more prevalent in } \\
\text { persistent compared to } \\
\text { intermittent asthma } \\
(p<0.001)\end{array}$ \\
\hline $\begin{array}{l}\text { Kumari et al. } \\
{[21], \text { India }}\end{array}$ & 1,101 & Cross-sectional & ROME III & 3.1 & 4.5 & $1.7(0.7-4.0)$ & 0.2 & Negative study \\
\hline
\end{tabular}

IBS, irritable bowel syndrome. 


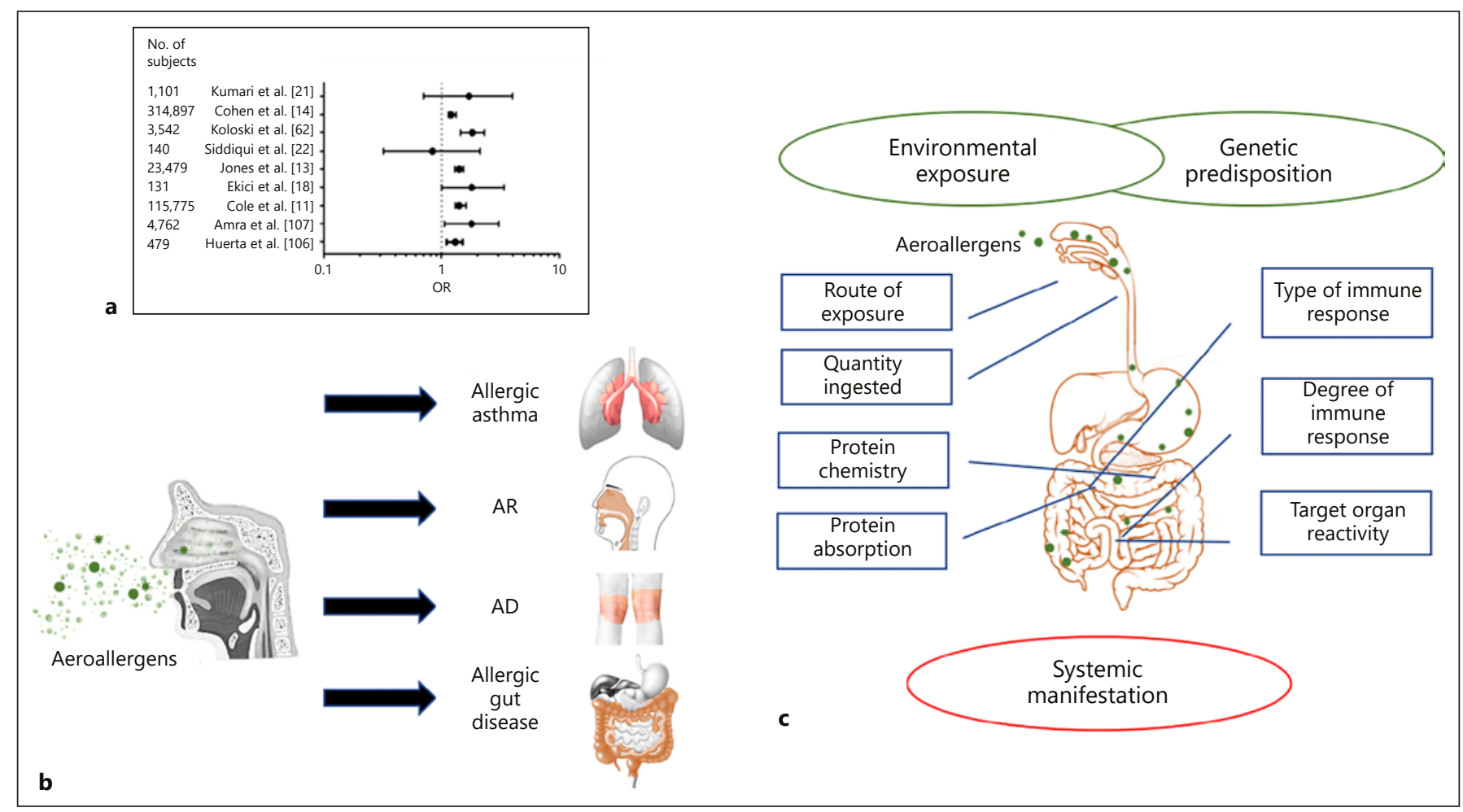

Fig. 1. a Forest plot of the association between asthma and IBS. b Sensitization to aeroallergen leads to asthma, $\mathrm{AR}, \mathrm{AD}$, and postulated allergic gut disease. $\mathbf{c}$ The possible role of genetic and environmental factors determining allergic reaction of aeroallergen in the gastrointestinal tract. AR, allergic rhinitis; AD, atopic dermatitis.

ments study with a follow-up of 1,037 children to the age of 26 years also showed no association between IBS and respiratory syndromes [23]. Nybacka et al. [24] showed that IBS patients did not have more atopic diseases compared to healthy controls. They recruited 223 IBS patients and 47 controls, out of which, there were $55 \%$ of IBS patients with atopic diseases compared to $40 \%$ in the control group $(p=0.07)$. There are several possible reasons for the contrasting findings observed in these studies. First, the aforementioned studies applied different diagnostic criteria for IBS (including ROME and Manning criteria) which may have underestimated the heterogeneity of IBS patients, causing them to overlook the presence of a subset of patients with allergy-related IBS. This subgroup may be better understood through studies that directly compare atopic against non-atopic IBS patients or studies which look for IBS symptoms in atopic patients. Second, the studies varied in their definition of atopy, including atopic manifestations during childhood [24], seasonal allergies [8], and the presence of urticaria [25] or conjunctivitis [13]. Details of the studies are presented in Table 1.

\section{$I B S$ and $A R$}

Several studies suggest a link between AR and IBS. In Taiwan, a retrospective study showed that children with antecedent allergic diseases had a greater risk of IBS than did control subjects. Among allergic conjunctivitis, AR, asthma, AD, urticaria, and food allergy, the highest adjusted odds ratio was observed among AR patients (OR 1.78) [26]. Similarly in UK, a retrospective chart review of 30,000 primary care records found that AR (OR 1.90, 95\% CI 1.65-2.20) and eczema (OR 1.46, 95\% CI 1.33-1.61) were significantly associated with IBS, even after controlling for age, gender, and mood disorders [13]. Tobin et al. [8] showed that AR and allergic eczema patients were 2.67 and 3.85 times more likely to develop IBS compared to healthy controls. In another retrospective case-control study of 7,235 adult patients, gastrointestinal problems were found to be significantly more common in patients with AR (7.9\%) compared to those with chronic illnesses (4.9\%) and the healthy population (5.5\%) [3]. Data from the population-based Västerbotten Environmental Health Study also showed that IBS was comorbid with allergic asthma and AR [27]. 


\section{IBS and Allergic Dermatitis}

IBS has also been highly associated with AD. In a Taiwanese cohort study involving 24,208 AD-diagnosed children and controls, children with $\mathrm{AD}$ had a 1.45 -fold greater risk of developing IBS than non-AD children [28]. Nybacka et al. [24] also showed that IBS patients recruited in a Swedish hospital had a higher prevalence of $\mathrm{AD}$ (31 vs. $21 \%, p=0.019$ ) as compared to healthy controls. In another study involving 125 adult patients in Chicago, $51 \%$ of patients with IBS reported having allergic dermatitis compared to only $18 \%$ of non-IBS patients. In fact, the presence of $\mathrm{AD}$ is an independent predictor of IBS diagnosis [8]. Bansal et al. [29] also reported an increased prevalence of IBS in patients with $\mathrm{AD}$, suggesting that $\mathrm{AD}$ may precede the development of IBS or be a marker for IBS.

\section{Genetics}

Several studies have explored the genetic risk factors shared between atopic diseases and IBS. Walker et al. [30] reviewed genome-wide association studies that looked at overlapping loci between atopic diseases, IBD, and gastrointestinal disorders. There were 7 nucleotide polymorphisms in the genes (IL-2, DENND1B, SMAD3, ORM$D L 3, H L A B, T N F S F 15)$ that were shared between atopic diseases and IBD, suggesting the involvement of the immune response in both condition's biological pathways. Patients with allergic disease, IBS, and IBD also show polymorphisms at loci encoding Toll-like receptors and the nucleotide-binding oligomerization domain like family of intracellular pattern recognition receptors. These findings suggest an involvement of genetic polymorphisms affecting the innate, immunological recognition of microbes [31, 32]. Another review by Lee and Park [33] has also shown the involvement of the TNFSF15 gene (identified in genome-wide association studies) to bring about mucosal inflammation in IBS and IBD [34]. Similar findings were made in cohort studies in the United States, United Kingdom, and Sweden [35, 36]. Like IBS, TNFSF15-TNFRSF25 signaling is also implicated in allergic diseases, suggesting the involvement of a shared inflammatory pathway [37]. TNFSF15 is a TNF family cytokine (TL1A) that is involved in the co-stimulation of type 2 innate lymphocytes and $\mathrm{T}$ cells by binding to the TNFRSF25 (DF3) receptor, inducing both the production of T helper 2 cytokines and Th9 differentiation with the subsequent promotion of allergic immunopathology [38, 39].

IBS: An Allergic Gut Disease?

\section{Environmental Factors}

The impact of environmental factors on chronic diseases and human health has been gaining attention in the past decade. Worsening air quality, for example, has been associated with a growing incidence of IBS and allergic diseases. In a Taiwan-based study involving 254, 207 children $(<18$ years of age), the increase in the number of newly diagnosed cases of IBS was associated with increases in the concentration of carbon monoxide, non-methane hydrocarbons, nitrogen dioxide, and methane, as detected from air quality monitoring stations nationwide [40]. In a meta-analysis of 12 birth cohort studies in Europe and North America, increased exposure to nitrogen dioxide and particulate matter was found to be associated with an increased incidence of asthma [41]. Similarly, Lee et al. [42] found a positive association between AR and air pollutants (such as carbon monoxide and nitrogen oxides) in children who attended schools within $2 \mathrm{~km}$ of air monitoring stations in Taiwan. These studies suggest that exposure to air pollutants may contribute to the pathogenesis of both IBS and allergic diseases.

\section{Aeroallergen and GI Tract}

While the role of food allergy in IBS has been studied extensively [43-45], the role of aeroallergens has not. Aeroallergens, such as house dust mites (HDM), pollens, mold, and animal dander, can reach our respiratory tracts through inhalation or our gastrointestinal tract through ingestion [46]. Based on the aerodynamics of human nasal airflow, over $80-90 \%$ of small particles in the inhalant air are trapped on the surface of the nasal mucosa [47] and are transported by the mucociliary apparatus to the pharynx where they are either swallowed or coughed out. However, aeroallergens can still contaminate the food that we eat. Foods containing aeroallergens can cause allergic reactions such as oral mite anaphylaxis. Oral mite anaphylaxis is a relatively new hypersensitivity syndrome characterized by an immediate allergic reaction to mite contained in food. It is normally found in patients with IgE-mediated hypersensitization to HDMs [48, 49]. Food can also be easily contaminated by aeroallergens from furred animals and pollen grains [50].

Aeroallergens may contribute to the pathogenesis of asthma and IBS. For example, AD, food allergy, and asthma are each associated with the development of eosinophilic esophagitis (EoE): an esophageal disease characterized by eosinophil-predominant inflammation [51]. Re-

Int Arch Allergy Immunol 2020;181:31-42 DOI: 10.1159/000503629 
peated exposure to aeroallergens in EoE can produce esophageal eosinophilia [52]. An experimental animal study showed that EoE could be induced by intranasal instillation of dust mite, Aspergillus fumigatus, and cockroach [53]. In patients allergic to birch pollen, exposure to birch pollen produces local duodenal inflammation with increased eosinophils and IgE-carrying mast cells [54]. In a retrospective cohort study by Wauters et al. [55], duodenal eosinophils counts were higher in FD patients compared to controls. Of note, the incidence of atopic diseases in this study was higher in FD patients compared to controls.

A number of studies have shown that IBS patients are more sensitized to aeroallergens. A study by VivinusNébot et al. [56] showed that IBS patients with atopic diseases had more severe disease and diarrhea-predominant symptoms. In the same study, it was shown that IBS patients had a higher sensitivity to inhalant allergens, but not food allergens, as compared with controls. In Sweden, Nybacka et al. [24] assessed the prevalence of self-reported atopy in IBS patients. They found a higher prevalence of IBS in atopic patients compared to controls, albeit without statistical significance (55 vs. $40 \%, p=0.07$ ). They also found that atopic IBS patients had higher levels of total serum $\operatorname{IgE}(p<0.001)$ and aeroallergen allergy (but not food allergy) than non-atopic IBS patients $(p<$ 0.001) [24]. Fang et al. [57] performed a retrospective case-control study of 108 atopic patients in China and observed that atopic patients with HDM-specific $\operatorname{IgE}$ were more likely to have abdominal bloating (OR 3.640; $95 \%$ CI 1.228-10.790, $p<0.05)$. The severity of abdominal bloating was directly related to total IgE levels [57]. Another small clinical study in the US reported significant differences in sensitization rates towards Dermatophagoides pteronisimus and Dermatophagoides farinae for patients with IBS compared to the control group [58]. In addition, more IBS patients were sensitized to both dust mites compared to control (38.8 vs. $10 \%, p<0.005)$. These results indicate a possibility that aeroallergens may potentially be a key environmental trigger in the pathogenesis of IBS.

How can aeroallergens withstand the digestive process? Strong evidence on the stability of aeroallergens in the gut is provided by Tulic et al. [59]. They found Der p1 antigen (a major HDM antigen) in the duodenal fluid of participants as well as in all regions of the gut including the large bowel. Besides bringing about gastrointestinal inflammation, HDM is capable of weakening intestinal barrier function in participants with IBS [59]. Exposure and sensitization to aeroallergens are closely linked to al- lergic diseases, particularly asthma. In fact, aeroallergen sensitization is a risk factor for poorly controlled diseases. We often link exposure to aeroallergens to certain environmental conditions, such as HDM with dusty environments and cat dander with animal exposure. We know that HDM exposure is related to asthma severity [60]. While there is currently no study linking HDM exposure to IBS, several studies have linked pet exposure to IBS. In an epidemiological study in Singapore, Siah et al. [61] showed that pet owners were 2.5 times more likely to develop IBS compared to those without pets. Similarly, Koloski et al. [62] found that exposure to herbivorous pets was a risk factor for both IBS and FD.

\section{Sublingual Immunotherapy and Associated Gastrointestinal Problems}

Sublingual immunotherapy refers to repeatedly exposing patients to small doses of allergen by placing it under the tongue. Substantial evidence has been presented by several groups on gastrointestinal problems associated with sublingual immunotherapy. A meta-analysis of randomized controlled trials on the efficacy of sublingual immunotherapy in the treatment of pediatric AR reported that gastrointestinal problems were one of the most common adverse effects of treatment [63]. In a sublingual immunotherapy trial involving Dermatophagoides farinae (a HDM antigen) in the United States, gastrointestinal symptoms were reported as one of the adverse side effects. Of note, one subject with IBS experienced an increase in diarrheic symptoms while receiving a low dose of sublingual immunotherapy treatment [64]. In another multisite, randomized trial in France and Spain that included 219 subjects with AR with or without asthma, one of the most frequent immunotherapy-related adverse reactions reported was upper abdominal pain [65].

\section{Pathophysiology}

\section{Possible Mechanisms Linking IBS and Allergic}

Diseases

Immune Responses

Both allergic diseases and IBS are brought about by immune dysregulation in genetically susceptible hosts [66]. IBS has been linked to defects in intestinal permeability and subsequent diarrhea. Mucosal immune activation results in the production of immune mediators such as cytokines, histamine, and prostaglandins which stimu-
36

Int Arch Allergy Immunol 2020;181:31-42 DOI: $10.1159 / 000503629$
Loo/Wang/Siah 
late epithelial ion secretion. In addition, mast cell proteases activate downstream effects by cleaving protease-activated receptors, which in turn results in the secretion of ions in colonic mucosa $[6,67]$.

Besides being involved in IBS pathogenesis, mast cells also play a central role in allergic inflammation. Exposure to environmental allergens in the environment will lead to the synthesis of allergen-specific IgE in susceptible individuals. Newly synthesized IgEs will bind to FceRI receptors on mast cells and basophils. On re-exposure to the specific allergen, mast cells and basophils produce mediators that result in allergic reaction. Mast cells and basophils are central to the initiation and propagation of immediate hypersensitivity reactions. Principal among the cells drawn to sites of mediator release is the eosinophil.

Multiple studies report increased numbers of mast cells and mast cell products (including tryptase, histamine, and prostaglandins) in the small and large bowel of IBS patients. Weston et al. [68] reported high levels of mast cells in the terminal ileum of IBS patients as early as 1993. Many other studies have revealed the role of mast cells in immune activation and causing symptoms such as abdominal pain and altered GI motility in IBS patients [69-72]. Barbara et al. [69] performed a seminal study in this area. They compared the colonic mucosa of IBS and healthy controls and showed that IBS patients had increased mast cells with a higher release of tryptase and histamine. Furthermore, they showed that in IBS patients, masts cells located closer to mucosal innervation were significantly correlated with the severity and frequency of abdominal pain or discomfort [69]. In another study, Cremon et al. [73] showed that mucosal mast cell infiltration in IBS patients was significantly associated with abdominal bloating frequency and symptoms of dysmotility-like dyspepsia. Barbara et al. [74] also showed that biopsy supernatants from patients with IBS contained higher amounts of mast cell mediators, including proteases and histamines. Bashashati et al. [75] performed a systematic review and meta-analysis of colonic immune cells in IBS and found that mast cells were increased in the sigmoid rectum and descending colon in IBS patients. There are many postulated pathophysiological mechanisms regarding the involvement of mast cells in IBS exist, including undetected food allergies, stress, and postinfectious IBS [72, 74, 76-79]. Findings of anti-mast cells treatment in IBS patients are presented in Table 2.

As described above, IgE is known to play a central role in the pathophysiology of type I hypersensitivity reactions [80]. Multiple studies have shown that higher level of IgEs is associated with IBS [81]. Fang et al. [57] showed that atopic patients had higher IgE levels and were more likely to have abdominal bloating; total IgE level was also independently associated with bloating in atopic patients. Atopic patients also had increased intestinal permeability and density of IgE-bearing mast cells compared with non-atopic patients [82].

\section{Structural Defects}

Adherens junctions, tight junctions, and desmosomes govern the integrity of the intestinal epithelial barrier. Evidence from a few studies has shown the involvement of increased intestinal permeability and defective epithelial barrier in the pathogenesis of IBS [83-85]. Jejunal biopsies from IBS-D patients show differential expression in genes related to mast cells and the intercellular apical junction complex compared to healthy subjects [86]. Besides, structural abnormalities at the apical junction complex have also been found in jejunal mucosa of IBS-D subjects [87]. E-cadherin is a major component of adherens junctions and tight junctions. Defects in E-cadherin have also been found in people with $\mathrm{AD}[88,89]$. These findings highlight a possible link between IBS and eczema that could possibly be mediated through an impaired epithelial barrier. Other than defects in E-cadherin in eczema, loss of E-cadherin has also been found in bronchial epithelial cell biopsies from asthmatic subjects [90]. Bronchial biopsies from asthmatic subjects have revealed tight junction disruption. Differentiated bronchial epithelial cultures show significant reductions in tight junction formation from asthmatic subjects $(n=43)$ compared to normal subjects $(n=40)$ [91]. This disruption in tight junction formation correlates with macromolecular permeability, suggesting that this defect may facilitate the entry of allergens into the host.

\section{Gut Microbiota}

It is known that patients with IBS and allergic diseases have alterations in gut microbiome composition, including an increased abundance of Firmicutes and reduced abundance of Bacteroides [92]. Lower abundance of members of the Bifidobacterium genera has been reported in children with IBS-D (diarrhea-predominant IBS) compared to healthy volunteers [93]. Similarly, children with asthma were also found to have a lower abundance of members of Bifidobacterium adolescentis [94]. In another study in Turkey, stool samples from allergic and non-allergic children ( $0-3$ years old) were compared. It was found that Bifidobacterium longum was detected in only $11.1 \%$ of the allergic children as compared to $30.3 \%$ 
Table 2. Anti-allergic drug trials in IBS

\begin{tabular}{|c|c|c|c|c|}
\hline $\begin{array}{l}\text { Placebo-controlled } \\
\text { randomized control } \\
\text { trial }\end{array}$ & Ketotifen & $\begin{array}{l}\text { Anti-histamine } 1 \\
\text { receptor and mast } \\
\text { cell stabilizer }\end{array}$ & Positive & $\begin{array}{l}\text { Decreases visceral hypersensitivity and IBS } \\
\text { symptoms }\end{array}$ \\
\hline $\begin{array}{l}\text { Randomized control } \\
\text { trial }\end{array}$ & $\begin{array}{l}\text { Sodium } \\
\text { Cromoglycate }\end{array}$ & $\begin{array}{l}\text { Inhibit mast cell } \\
\text { degranulation }\end{array}$ & Positive & $\begin{array}{l}\text { Combination of dietary exclusion and } \\
\text { cromoglycate better than dietary intervention } \\
\text { alone for IBS-D with food intolerance (by SPT) }\end{array}$ \\
\hline Open label & $\begin{array}{l}\text { Sodium } \\
\text { Cromoglycate }\end{array}$ & $\begin{array}{l}\text { Inhibit mast cell } \\
\text { degranulation }\end{array}$ & Positive & $\begin{array}{l}\text { Decreased mucosal mast cells activation in } \\
\text { jejunal biopsies, reduced abdominal pain and } \\
\text { bowel habits in IBS-D }\end{array}$ \\
\hline Case report & Omalizumab & $\begin{array}{l}\text { Anti-IgE monoclonal } \\
\text { antibody }\end{array}$ & Positive & $\begin{array}{l}\text { Treatment of chronic urticaria also improved } \\
\text { IBS }\end{array}$ \\
\hline $\begin{array}{l}\text { Placebo-controlled } \\
\text { randomized control } \\
\text { trial }\end{array}$ & Ebastine & $\begin{array}{l}\text { Histamine } 1 \text { receptor } \\
\text { antagonist }\end{array}$ & Positive & $\begin{array}{l}\text { Reduced visceral hypersensitivity, increased } \\
\text { symptom relief (and reduced abdominal pain } \\
\text { scores) }\end{array}$ \\
\hline
\end{tabular}

IBS, irritable bowel syndrome.

of the healthy children [95]. This shows that alterations in gut microbiota may occur early in life and may later drive the development of IBS and allergic diseases.

The microbial metabolites produced may also play a role in the pathogenesis of IBS $[96,97]$. Recent evidence shows that the regulatory functions of intestinal macrophages by butyrate [98], a short-chain fatty acid, are altered in IBS and AD/allergic disease [99, 100]. This finding highlights the implication of gut microbiota and immunomodulatory pathways in the pathogenesis of both IBS and allergic diseases.

Rodent studies have shown that the ingestion of particulate matter induces changes in the gut microbiota's composition and function [101]. Similar to the altered microbiota composition seen in IBS and allergic patients, IL $10^{-/-}$mice were also found to have significantly increased abundance in Firmicutes, decreased abundance in Bacteroides, and a lower concentration of butyrate [101]. Reduction in butyrate is known to bring about a decrease in barrier function as well as reduce defense against inflammation $[102,103]$.

\section{Five Criteria to Establish a Pathomechanism: Role of Aeroallergen in IBS}

In 2016, a group of international experts on FGIDs (together with the publication of ROME IV criteria for FGIDs) proposed criteria to be considered for potential, pathophysiological mechanisms for FGIDs [104]. To establish a causal relationship between a particular mechanism and FGID symptoms, several criteria needed to be met, including the presence, temporal association, a correlation between the level of impairment and symptom severity, induction in healthy subjects, and treatment response or congruent natural history. Based on the strength of evidence for these 5 criteria, a plausibility score can be calculated for each mechanism. As an example of a potential, pathophysiological mechanism, Table 3 presents the role of acid in gastroesophageal reflux disease.

There have been many studies showing an increased sensitization to aeroallergens in IBS patients. However, it is unknown how long it takes for an aeroallergen to produce a reaction (ingestion vs. direct inoculation) and illicit anticipated symptoms (pain vs. motility). Unlike other allergic diseases, the link between allergy and IBS still requires ex- 
Table 3. Five criteria to establish a pathomechanism: role of aeroallergen in IBS

\begin{tabular}{|c|c|c|c|}
\hline & Meaning & Role of acid in GERD & Role of aeroallergen in IBS \\
\hline 1 Presence & $\begin{array}{l}\text { The presence of abnormality } \\
\text { in a subset of patients }\end{array}$ & $\begin{array}{l}\text { The finding of increased } \\
\text { esophageal acid exposure } \\
\text { on pH monitoring in patients } \\
\text { with heartburn }\end{array}$ & $\begin{array}{l}\text { The finding of increased aeroallergen } \\
\text { sensitization in IBS patients }\end{array}$ \\
\hline $\begin{array}{l}2 \text { Temporal } \\
\text { association }\end{array}$ & $\begin{array}{l}\text { Temporal association between } \\
\text { proposed mechanism and } \\
\text { symptom }(\mathrm{s})\end{array}$ & $\begin{array}{l}\text { The temporal association } \\
\text { between reflux events and } \\
\text { heartburn occurrence }\end{array}$ & No evidence \\
\hline 3 Correlation & $\begin{array}{l}\text { Correlation between the level of } \\
\text { impairment of the mechanism } \\
\text { and symptom(s) }\end{array}$ & $\begin{array}{l}\text { The worsening of heartburn scores } \\
\text { with increasing severity } \\
\text { of esophageal acid exposure }\end{array}$ & $\begin{array}{l}\text { Indirect evidence. The association } \\
\text { of bloating in IBS patient with HDM } \\
\text { sensitization and worsening of } \\
\text { bloating with increasing IgE level. } \\
\text { Worsening of IBS symptoms with } \\
\text { allergic factors }\end{array}$ \\
\hline 4 Induction & $\begin{array}{l}\text { Induction of the symptom(s) by } \\
\text { provoking the pathophysiological } \\
\text { abnormality in healthy subjects }\end{array}$ & $\begin{array}{l}\text { The induction of heartburn by } \\
\text { esophageal acid perfusion }\end{array}$ & No evidence \\
\hline $\begin{array}{l}5 \text { Treatment } \\
\text { response }\end{array}$ & $\begin{array}{l}\text { Treatment response by a therapy } \\
\text { specifically correcting the } \\
\text { underlying disorder or congruent } \\
\text { natural history of symptoms and } \\
\text { dysfunction in the absence of } \\
\text { specific therapy }\end{array}$ & $\begin{array}{l}\text { The response of symptoms to } \\
\text { acid-suppressive therapy }\end{array}$ & $\begin{array}{l}\text { The response of IBS symptoms to } \\
\text { anti-histamine or anti-allergy } \\
\text { therapy }\end{array}$ \\
\hline
\end{tabular}

IBS, irritable bowel syndrome; HDM, house dust mite.

tensive research on temporal association (the ability to observe or detect immediately delayed symptoms), correlation (to determine a dose-response relationship, both internally and externally), and induction (the direct observation of an inflammatory reaction alongside the elicitation of IBS symptoms) [105]. Even though the development of allergies to aeroallergens may not be the only pathophysiological mechanism which explains IBS symptoms, it is plausible that aeroallergens may act like a catalyst that impairs gut barrier function and facilitates the pathogenic mechanisms of other pathogens or gut microorganisms.

\section{Clinical Implications}

Allergic diseases and IBS are two very common conditions in the community. It is not unusual to find them co-existing in a single patient. However, our review shows that perhaps there might be a connection between a subset of IBS patients and allergic diseases. Due to the chronic and complex nature of IBS, all avenues that may lead to better treatment must be carefully explored. No stone should be left unturned.

\section{Conclusion}

There is suggestive and supportive evidence with regard to the link between irritable bowel disease and allergic diseases. Future work should focus on confirming the underlying biological mechanisms that are involved in the pathogenesis of these diseases so as to derive preventive and treatment strategies for better patient care.

\section{Acknowledgement}

We would like to thank Charles Chandler Herndon for helping with language editing.

\section{Disclosure Statement}

The authors have no conflicts of interest to declare. 


\section{Funding Sources}

None.

\section{References}

1 Cremonini F, Talley NJ. Irritable bowel syndrome: epidemiology, natural history, health care seeking and emerging risk factors. Gastroenterol Clin North Am. 2005 Jun;34(2): 189-204.

2 Enck P, Aziz Q, Barbara G, Farmer AD, Fukudo S, Mayer EA, et al. Irritable bowel syndrome. Nat Rev Dis Primers. 2016 Mar;2(1): 16014.

3 Powell N, Huntley B, Beech T, Knight W, Knight $\mathrm{H}$, Corrigan CJ. Increased prevalence of gastrointestinal symptoms in patients with allergic disease. Postgrad Med J. 2007 Mar; 83(977):182-6.

4 Shen TC, Lin CL, Wei CC, Chen CH, Tu CY, Hsia TC, et al. Bidirectional Association between Asthma and Irritable Bowel Syndrome: Two Population-Based Retrospective Cohort Studies. PLoS One. 2016 Apr;11(4):e0153911.

5 Lambrecht BN, Hammad H. The immunology of the allergy epidemic and the hygiene hypothesis. Nat Immunol. 2017 Sep;18(10): 1076-83.

6 Lee KN, Lee OY. The Role of Mast Cells in Irritable Bowel Syndrome. Gastroenterol Res Pract. 2016;2016:2031480.

7 Farhadi A, Fields JZ, Keshavarzian A. Mucosal mast cells are pivotal elements in inflammatory bowel disease that connect the dots: stress, intestinal hyperpermeability and inflammation. World J Gastroenterol. 2007 Jun; 13(22):3027-30.

8 Tobin MC, Moparty B, Farhadi A, DeMeo MT, Bansal PJ, Keshavarzian A. Atopic irritable bowel syndrome: a novel subgroup of irritable bowel syndrome with allergic manifestations. Ann Allergy Asthma Immunol. 2008 Jan;100(1):49-53.

9 White AM, Stevens WH, Upton AR, O'Byrne $\mathrm{PM}$, Collins SM. Airway responsiveness to inhaled methacholine in patients with irritable bowel syndrome. Gastroenterology. 1991 Jan; 100(1):68-74.

10 Kennedy TM, Jones RH, Hungin AP, O'flanagan H, Kelly P. Irritable bowel syndrome, gastro-oesophageal reflux, and bronchial hyper-responsiveness in the general population. Gut. 1998 Dec;43(6):770-4.

11 Cole JA, Rothman KJ, Cabral HJ, Zhang Y, Farraye FA. Incidence of IBS in a cohort of people with asthma. Dig Dis Sci. 2007 Feb; 52(2):329-35.

\section{Author Contributions}

E.X.L.L. and D.Y.W. were involved in the writing and critical review of the manuscript. K.T.H.S. conceptualized the idea and was involved in the writing of the manuscript.
12 Roussos A, Koursarakos P, Patsopoulos D, Gerogianni I, Philippou N. Increased prevalence of irritable bowel syndrome in patients with bronchial asthma. Respir Med. 2003 Jan; 97(1):75-9.

13 Jones MP, Walker MM, Ford AC, Talley NJ. The overlap of atopy and functional gastrointestinal disorders among 23,471 patients in primary care. Aliment Pharmacol Ther. 2014 Aug;40(4):382-91.

14 Cohen S, Berkman N, Picard E, Levi T, Derazne $\mathrm{E}$, Tzur $\mathrm{D}$, et al. Co-morbidities and cognitive status in a cohort of teenagers with asthma. Pediatr Pulmonol. 2016 Sep;51(9): 901-7.

15 Caffarelli C, Deriu FM, Terzi V, Perrone F, De Angelis G, Atherton DJ. Gastrointestinal symptoms in patients with asthma. Arch Dis Child. 2000 Feb;82(2):131-5.

16 Colman RJ, Rosario NB, Gutierrez Bonilla A, Benavidez Alvarez G, Benavidez Alvarez J, Uy VP, et al. Prevalence of functional GI disorders among pediatric patients with persistent asthma. J Dig Dis. 2018 Sep;19(9): 522-8.

17 Olén O, Neuman Å, Koopmann B, Ludvigsson JF, Ballardini N, Westman M, et al. Allergy-related diseases and recurrent abdominal pain during childhood - a birth cohort study. Aliment Pharmacol Ther. 2014 Dec;40(1112):1349-58.

18 Ekici A, Guliter S, Ekici M, Kalpaklioglu F, Kara T, Keles H, et al. Irritable bowel syndrome in young and elderly patients with stable asthma. Dig Liver Dis. 2005 Oct;37(10): 773-8.

19 Camilleri M, Lee JS, Viramontes B, Bharucha $\mathrm{AE}$, Tangalos EG. Insights into the pathophysiology and mechanisms of constipation, irritable bowel syndrome, and diverticulosis in older people. J Am Geriatr Soc. 2000 Sep; 48(9):1142-50.

20 Till RE, Franklin LD. On the locus of age differences in visual information processing. J Gerontol. 1981 Mar;36(2):200-10.

21 Kumari MV, Devanarayana NM, Amarasiri L, Rajindrajith S. Association between functional abdominal pain disorders and asthma in adolescents: A cross-sectional study. World J Clin Cases. 2018 Dec;6(15):944-51.

22 Siddiqui S, Misra SP, Dwivedi M, Pant S. Irritable Bowel Syndrome and Bronchial Asthma: Are They Associated in Indian Population? J Clin Diagn Res. 2017 Feb;11(2):OC213.
23 Hancox RJ, Poulton R, Taylor DR, Greene JM, McLachlan CR, Cowan JO, et al. Associations between respiratory symptoms, lung function and gastro-oesophageal reflux symptoms in a population-based birth cohort. Respir Res. 2006 Dec;7(1):142.

24 Nybacka S, Öhman L, Störsrud S, Mybeck M, Böhn L, Wilpart K, et al. Neither self-reported atopy nor IgE-mediated allergy are linked to gastrointestinal symptoms in patients with irritable bowel syndrome. Neurogastroenterol Motil. 2018 Oct;30(10):e13379.

25 Vara EJ, Svanes C, Skorge TD, Berstad A, Florvaag E, Jarvis D, et al. Functional Gastrointestinal Symptoms Are Associated with Higher Serum Total IgE Levels, but Less Atopic Sensitization. Dig Dis Sci. 2016 Jan;61(1): 189-97.

26 Tan TK, Chen AC, Lin CL, Shen TC, Li TC, Wei CC. Preschoolers With Allergic Diseases Have an Increased Risk of Irritable Bowel Syndrome When Reaching School Age. J Pediatr Gastroenterol Nutr. 2017 Jan;64(1):2630.

27 Tsiakiris G, Neely G, Lind N, Nordin S. Comorbidity in allergic asthma and allergic rhinitis: functional somatic syndromes. Psychol Health Med. 2017 Dec;22(10):1163-8.

28 Tsai JD, Wang IC, Shen TC, Lin CL, Wei CC. A 8-year population-based cohort study of irritable bowel syndrome in childhood with history of atopic dermatitis. J Investig Med. 2018 Apr;66(4):755-61.

29 Bansal PJ, Moparty B, DeMeo MT, Farhadi A, Keshavarzian A, Tobin MC. Atopic dermatitis as an allergic marker for irritable bowel syndrome. J Allergy Clin Immunol. 2003; 111(2 Supplement 1):S157.

30 Walker MM, Powell N, Talley NJ. Atopy and the gastrointestinal tract-a review of a common association in unexplained gastrointestinal disease. Expert Rev Gastroenterol Hepatol. 2014 Mar;8(3):289-99.

31 Bønnelykke K, Matheson MC, Pers TH, Granell R, Strachan DP, Alves AC, et al.; AAGC. Meta-analysis of genome-wide association studies identifies ten loci influencing allergic sensitization. Nat Genet. 2013 Aug; 45(8):902-6.

32 Jostins L, Ripke S, Weersma RK, Duerr RH, McGovern DP, Hui KY, et al.; International IBD Genetics Consortium (IIBDGC). Hostmicrobe interactions have shaped the genetic architecture of inflammatory bowel disease. Nature. 2012 Nov;491(7422):119-24. 
33 Lee YJ, Park KS. Irritable bowel syndrome: emerging paradigm in pathophysiology. World J Gastroenterol. 2014 Mar;20(10): 2456-69.

34 Gonsky R, Deem RL, Targan SR. Multiple activating and repressive cis-promoter regions regulate TNFSF15 expression in human primary mononuclear cells. Cytokine. 2013 Jul; 63(1):36-42.

35 Swan C, Duroudier NP, Campbell E, Zaitoun A, Hastings M, Dukes GE, et al. Identifying and testing candidate genetic polymorphisms in the irritable bowel syndrome (IBS): association with TNFSF15 and TNFa. Gut. 2013 Jul;62(7):985-94.

36 Zucchelli M, Camilleri M, Andreasson AN, Bresso F, Dlugosz A, Halfvarson J, et al. Association of TNFSF15 polymorphism with irritable bowel syndrome. Gut. 2011 Dec; 60(12):1671-7.

37 Schreiber TH, Wolf D, Podack ER. The Role of TNFRSF25:TNFSF15 in Disease and Health? New York: Springer New York; 2011.

38 Meylan F, Hawley ET, Barron L, Barlow JL, Penumetcha P, Pelletier M, et al. The TNFfamily cytokine TL1A promotes allergic immunopathology through group 2 innate lymphoid cells. Mucosal Immunol. 2014 Jul; 7(4): 958-68.

39 Richard AC, Tan C, Hawley ET, Gomez-Rodriguez J, Goswami R, Yang XP, et al. The TNF-family ligand TL1A and its receptor DR3 promote T cell-mediated allergic immunopathology by enhancing differentiation and pathogenicity of IL-9-producing T cells. J Immunol. 2015 Apr;194(8):3567-82.

40 Tan TK, Saps M, Lin CL, Wei CC. Is Longterm Ambient Air Pollutant Exposure a Risk Factor for Irritable Bowel Syndrome in Children? A 12-year Longitudinal Cohort Study. J Neurogastroenterol Motil. 2019 Apr;25(2): 241-9.

41 Bowatte G, Lodge C, Lowe AJ, Erbas B, Perret J, Abramson MJ, et al. The influence of childhood traffic-related air pollution exposure on asthma, allergy and sensitization: a systematic review and a meta-analysis of birth cohort studies. Allergy. 2015 Mar;70(3):245-56.

42 Lee YL, Shaw CK, Su HJ, Lai JS, Ko YC, Huang SL, et al. Climate, traffic-related air pollutants and allergic rhinitis prevalence in middleschool children in Taiwan. Eur Respir J. 2003 Jun;21(6):964-70.

43 Ozol D, Uz E, Bozalan R, Türkay C, Yildirim Z. Relationship between asthma and irritable bowel syndrome: role of food allergy. J Asthma. 2006 Dec;43(10):773-5.

44 Fritscher-Ravens A, Pflaum T, Mösinger M, Ruchay Z, Röcken C, Milla PJ, et al. Many Patients With Irritable Bowel Syndrome Have Atypical Food Allergies Not Associated With Immunoglobulin E. Gastroenterology. 2019 Jul;157(1):109-118.e5.

45 Renz H, Allen KJ, Sicherer SH, Sampson HA, Lack G, Beyer K, et al. Food allergy. Nat Rev Dis Primers. 2018 Jan;4(1):17098.
46 Tham EH, Lee AJ, Bever HV. Aeroallergen sensitization and allergic disease phenotypes in Asia. Asian Pac J Allergy Immunol. 2016 Sep;34(3):181-9.

47 Garlapati RR, Lee HP, Chong FH, Wang Y. Indicators for the correct usage of intranasal medications: A computational fluid dynamics study. Laryngoscope. 2009 Oct;119(10): 1975-82.

48 Sánchez-Borges $\mathrm{M}$, Suárez-Chacon $\mathrm{R}$, Capriles-Hulett A, Caballero-Fonseca F, Iraola V, Fernández-Caldas E. Pancake syndrome (oral mite anaphylaxis). World Allergy Organ J. 2009 May;2(5):91-6.

49 Tay SY, Tham E, Yeo CT, Yi FC, Chen JY, Cheong N, et al. Anaphylaxis following the in gestion of flour contaminated by house dust mites-a report of two cases from Singapore. Asian Pac J Allergy Immunol. 2008 Jun-Sep; 26(2-3):165-70.

50 Popescu FD, Vieru M. The presence of aeroallergens in food products: a potential risk for the patient with allergic rhinitis. Rom J Rhinol. 2018;8(29):11-5.

51 Hill DA, Grundmeier RW, Ramos M, Spergel JM. Eosinophilic Esophagitis Is a Late Manifestation of the Allergic March. J Allergy Clin Immunol Pract. 2018 Sep - Oct;6(5):1528-33.

52 Egan M, Atkins D. What Is the Relationship Between Eosinophilic Esophagitis (EoE) and Aeroallergens? Implications for Allergen Immunotherapy. Curr Allergy Asthma Rep. 2018 Jun;18(8):43.

53 Rayapudi M, Mavi P, Zhu X, Pandey AK, Abonia JP, Rothenberg ME, et al. Indoor insect allergens are potent inducers of experimental eosinophilic esophagitis in mice. J Leukoc Biol. 2010 Aug;88(2):337-46.

54 Magnusson J, Lin XP, Dahlman-Höglund A, Hanson L LA, Telemo E, Magnusson O, et al. Seasonal intestinal inflammation in patients with birch pollen allergy. J Allergy Clin Immunol. 2003 Jul;112(1):45-50.

55 Wauters L, Nightingale S, Talley NJ, Sulaiman $\mathrm{B}$, Walker MM. Functional dyspepsia is associated with duodenal eosinophilia in an Australian paediatric cohort. Aliment Pharmacol Ther. 2017 May;45(10):1358-64.

56 Vivinus-Nébot M, Dainese R, Anty R, SaintPaul MC, Nano JL, Gonthier N, et al. Combination of allergic factors can worsen diarrheic irritable bowel syndrome: role of barrier defects and mast cells. Am J Gastroenterol. 2012 Jan;107(1):75-81.

57 Fang ZY, Zhang HT, Lu C, Lu QM, Yu CH, Wang HY. Association between Allergic Diseases and Irritable Bowel Syndrome: A Retrospective Study. Int Arch Allergy Immunol. 2018;177(2):153-9.

58 Levchenko A, Romaniuk L, DuBuske I, Dubuske L. Sensitization to House Dust Mites in Patients with Irritable Bowel Syndrome. J Allergy Clin Immunol. 2018;141(2 Supplement):AB233.
59 Tulic MK, Vivinus-Nébot M, Rekima A, Rabelo Medeiros S, Bonnart C, Shi H, et al. Presence of commensal house dust mite allergen in human gastrointestinal tract: a potential contributor to intestinal barrier dysfunction. Gut. 2016 May;65(5):757-66.

60 Gaffin JM, Phipatanakul W. The role of indoor allergens in the development of asthma. Curr Opin Allergy Clin Immunol. 2009 Apr; 9(2):128-35.

61 Siah KT, Wong RK, Chan YH, Ho KY, Gwee KA; Prevalence of Irritable Bowel Syndrome in Singapore and Its Association with Dietary, Lifestyle, and Environmental Factors. Prevalence of Irritable Bowel Syndrome in Singapore and Its Association with Dietary, Lifestyle, and Environmental Factors. J Neurogastroenterol Motil. 2016 Oct;22(4):670-6.

62 Koloski NA, Jones M, Weltman M, Kalantar J, Bone C, Gowryshankar A, et al. Identification of early environmental risk factors for irritable bowel syndrome and dyspepsia. Neurogastroenterol Motil. 2015 Sep;27(9):131725.

63 Penagos M, Compalati E, Tarantini F, BaenaCagnani R, Huerta J, Passalacqua G, et al. Efficacy of sublingual immunotherapy in the treatment of allergic rhinitis in pediatric patients 3 to 18 years of age: a meta-analysis of randomized, placebo-controlled, doubleblind trials. Ann Allergy Asthma Immunol. 2006 Aug;97(2):141-8.

64 Bush RK, Swenson C, Fahlberg B, Evans MD, Esch R, Morris M, et al. House dust mite sublingual immunotherapy: results of a US trial. J Allergy Clin Immunol. 2011 Apr;127(4): 974-81.e1-7.

65 Didier A, Campo P, Moreno F, Durand-Perdriel F, Marin A, Chartier A. Dose-Dependent Immunological Responses after a 6-Month Course of Sublingual House Dust Mite Immunotherapy in Patients with Allergic Rhinitis. Int Arch Allergy Immunol. 2015;168(3): 182-92.

66 Keely S, Walker MM, Marks E, Talley NJ. Immune dysregulation in the functional gastrointestinal disorders. Eur J Clin Invest. 2015 Dec;45(12):1350-9.

67 Gao C, Liu S, Hu HZ, Gao N, Kim GY, Xia Y, et al. Serine proteases excite myenteric neurons through protease-activated receptors in guinea pig small intestine. Gastroenterology. 2002 Nov; 123(5):1554-64.

68 Weston AP, Biddle WL, Bhatia PS, Miner PB Jr. Terminal ileal mucosal mast cells in irritable bowel syndrome. Dig Dis Sci. 1993 Sep; 38(9):1590-5.

69 Barbara G, Stanghellini V, De Giorgio R, Cremon C, Cottrell GS, Santini D, et al. Activated mast cells in proximity to colonic nerves correlate with abdominal pain in irritable bowel syndrome. Gastroenterology. 2004 Mar; 126(3):693-702.

70 Bischoff SC. Mast cells in gastrointestinal disorders. Eur J Pharmacol. 2016 May;778:13945. 
71 O’Sullivan M, Clayton N, Breslin NP, Harman I, Bountra C, McLaren A, et al. Increased mast cells in the irritable bowel syndrome. Neurogastroenterol Motil. 2000 Oct;12(5): 449-57.

72 Wouters MM, Vicario M, Santos J. The role of mast cells in functional GI disorders. Gut. 2016 Jan;65(1):155-68.

73 Cremon C, Gargano L, Morselli-Labate AM, Santini D, Cogliandro RF, De Giorgio R, et al. Mucosal immune activation in irritable bowel syndrome: gender-dependence and association with digestive symptoms. Am J Gastroenterol. 2009 Feb;104(2):392-400.

74 Barbara G, Cremon C, Carini G, Bellacosa L, Zecchi L, De Giorgio R, et al. The immune system in irritable bowel syndrome. J Neurogastroenterol Motil. 2011 Oct;17(4):349-59.

75 Bashashati M, Moossavi S, Cremon C, Barbaro MR, Moraveji S, Talmon G, et al. Colonic immune cells in irritable bowel syndrome: A systematic review and meta-analysis. Neurogastroenterol Motil. 2018 Jan; 30(1):e13192.

76 Philpott H, Gibson P, Thien F. Irritable bowel syndrome - An inflammatory disease involving mast cells. Asia Pac Allergy. 2011 Apr; 1(1):36-42.

77 Piche T, Saint-Paul MC, Dainese R, MarineBarjoan E, Iannelli A, Montoya ML, et al. Mast cells and cellularity of the colonic mucosa correlated with fatigue and depression in irritable bowel syndrome. Gut. 2008 Apr; 57(4):468-73.

78 Walker MM, Warwick A, Ung C, Talley NJ. The role of eosinophils and mast cells in intestinal functional disease. Curr Gastroenterol Rep. 2011 Aug;13(4):323-30.

79 Zhang L, Song J, Hou X. Mast Cells and Irritable Bowel Syndrome: From the Bench to the Bedside. J Neurogastroenterol Motil. 2016 Apr;22(2):181-92.

80 Pearson JS, Niven RM, Meng J, Atarodi S, Whorwell PJ. Immunoglobulin $\mathrm{E}$ in irritable bowel syndrome: another target for treatment? A case report and literature review. Therap Adv Gastroenterol. 2015 Sep;8(5): 270-7.

81 Vara EJ, Valeur J, Hausken T, Lied GA. Extraintestinal symptoms in patients with irritable bowel syndrome: related to high total IgE levels and atopic sensitization? Scand J Gastroenterol. 2016 Aug;51(8):908-13.

82 Lillestøl K, Helgeland L, Arslan Lied G, Florvaag E, Valeur J, Lind R, et al. Indications of 'atopic bowel' in patients with self-reported food hypersensitivity. Aliment Pharmacol Ther. 2010 May;31(10):1112-22.

83 Barbara G. Mucosal barrier defects in irritable bowel syndrome. Who left the door open? Am J Gastroenterol. 2006 Jun;101(6):1295-8.

84 Camilleri M, Lasch K, Zhou W. Irritable bowel syndrome: methods, mechanisms, and pathophysiology. The confluence of increased permeability, inflammation, and pain in irritable bowel syndrome. Am J Physiol Gastrointest Liver Physiol. 2012 Oct;303(7):G775-85.
85 Dunlop SP, Hebden J, Campbell E, Naesdal J, Olbe L, Perkins AC, et al. Abnormal intestinal permeability in subgroups of diarrhea-predominant irritable bowel syndromes. Am J Gastroenterol. 2006 Jun;101(6):1288-94.

86 Martínez C, Vicario M, Ramos L, Lobo B, Mosquera JL, Alonso C, et al. The jejunum of diarrhea-predominant irritable bowel syndrome shows molecular alterations in the tight junction signaling pathway that are associated with mucosal pathobiology and clinical manifestations. Am J Gastroenterol. 2012 May;107(5):736-46.

87 Martínez C, Lobo B, Pigrau M, Ramos L, González-Castro AM, Alonso C, et al. Diarrhoea-predominant irritable bowel syndrome: an organic disorder with structural abnormalities in the jejunal epithelial barrier. Gut. 2013 Aug;62(8):1160-8.

88 Proksch E, Brandner JM, Jensen JM. Jensen, The skin: an indispensable barrier. Exp Dermatol. 2008 Dec;17(12):1063-72.

89 Trautmann A, Altznauer F, Akdis M, Simon HU, Disch R, Bröcker EB, et al. The differential fate of cadherins during T-cell-induced keratinocyte apoptosis leads to spongiosis in eczematous dermatitis. J Invest Dermatol. 2001 Oct;117(4):927-34.

90 Trautmann A, Kruger K, Akdis M, MullerWening D, Akkaya A, Brocker EB, et al. Apoptosis and loss of adhesion of bronchial epithelial cells in asthma. Int Arch Allergy Immunol. 2005 Oct; 138(2):142-50.

91 Xiao C, Puddicombe SM, Field S, Haywood J, Broughton-Head V, Puxeddu I, et al. Defective epithelial barrier function in asthma. J Allergy Clin Immunol. 2011 Sep;128(3):549-56. e1-12.

92 Ling Z, Li Z, Liu X, Cheng Y, Luo Y, Tong X, et al. Altered fecal microbiota composition associated with food allergy in infants. Appl Environ Microbiol. 2014 Apr;80(8):2546-54.

93 Rigsbee L, Agans R, Shankar V, Kenche H, Khamis HJ, Michail S, et al. Quantitative profiling of gut microbiota of children with diarrhea-predominant irritable bowel syndrome. Am J Gastroenterol. 2012 Nov; 107(11):174051.

94 Hevia A, Milani C, López P, Donado CD, Cuervo A, González S, et al. Allergic Patients with Long-Term Asthma Display Low Levels of Bifidobacterium adolescentis. PLoS One. 2016 Feb;11(2):e0147809.

95 Akay HK, Bahar Tokman H, Hatipoglu N, Hatipoglu H, Siraneci R, Demirci M, et al. The relationship between bifidobacteria and allergic asthma and/or allergic dermatitis: a prospective study of 0-3 years-old children in Turkey. Anaerobe. 2014 Aug;28:98-103.

96 Tana C, Umesaki Y, Imaoka A, Handa T, Kanazawa M, Fukudo S. Altered profiles of intestinal microbiota and organic acids may be the origin of symptoms in irritable bowel syndrome. Neurogastroenterol Motil. 2010 May;22(5):512-9, e114-5.
97 Treem WR, Ahsan N, Kastoff G, Hyams JS Fecal short-chain fatty acids in patients with diarrhea-predominant irritable bowel syndrome: in vitro studies of carbohydrate fermentation. J Pediatr Gastroenterol Nutr. 1996 Oct;23(3):280-6.

98 Chang PV, Hao L, Offermanns S, Medzhitov R. The microbial metabolite butyrate regulates intestinal macrophage function via histone deacetylase inhibition. Proc Natl Acad Sci USA. 2014 Feb;111(6):2247-52.

99 Salem I, Ramser A, Isham N, Ghannoum MA. The Gut Microbiome as a Major Regulator of the Gut-Skin Axis. Front Microbiol. 2018 Jul;9:1459-1459.

100 Simonyte Sjödin K, Vidman L, Rydén P, West CE. Emerging evidence of the role of gut microbiota in the development of allergic diseases. Curr Opin Allergy Clin Immunol. 2016 Aug;16(4):390-5.

101 Kish L, Hotte N, Kaplan GG, Vincent R, Tso $\mathrm{R}$, Gänzle M, et al. Environmental particulate matter induces murine intestinal inflammatory responses and alters the gut $\mathrm{mi}$ crobiome. PLoS One. 2013 Apr;8(4):e62220.

102 Parada Venegas D, De la Fuente MK, Landskron G, González MJ, Quera R, Dijkstra G, et al. Short Chain Fatty Acids (SCFAs)-Mediated Gut Epithelial and Immune Regulation and Its Relevance for Inflammatory Bowel Diseases. Front Immunol. 2019 Mar; 10:277.

103 Canani RB, Costanzo MD, Leone L, Pedata M, Meli R, Calignano A. Potential beneficial effects of butyrate in intestinal and extraintestinal diseases. World J Gastroenterol. 2011 Mar; 17(12):1519-28.

104 Tack J, Corsetti M, Camilleri M, Quigley EM, Simren M, Suzuki H, et al. Plausibility criteria for putative pathophysiological mechanisms in functional gastrointestinal disorders: a consensus of experts. Gut. 2018 Aug;67(8):1425-33.

105 Bischoff SC, Mayer J, Wedemeyer J, Meier PN, Zeck-Kapp G, Wedi B, et al. Colonoscopic allergen provocation (COLAP): a new diagnostic approach for gastrointestinal food allergy. Gut. 1997 Jun;40(6):745-53.

106 Huerta C, García Rodríguez LA, Wallander MA, Johansson S. Risk of irritable bowel syndrome among asthma patients. Pharmacoepidemiol Drug Saf. 2002 Jan-Feb;11(1):31-5.

107 Amra B, Hoseini-Asl MK, Rahmani AR, Golshan M, Mohamad-Zadeh Z. Correlation between asthma and irritable bowel syndrome in a general population in Iran in 2003. Respir Med. 2006 Jan;100(1):110-4.

108 Panicker R, Arifhodzic N, Al Ahmad M, Ali SA. Association and symptom characteristics of irritable bowel syndrome among bronchial asthma patients in Kuwait. Ann Thorac Med. 2010 Jan;5(1):37-42.

109 Yilmaz A, Cumurcu BE, Tasliyurt T, Sahan AG, Ustun Y, Etikan I. Role of psychiatric disorders and irritable bowel syndrome in asthma patients. Clinics (Sao Paulo). 2011; 66(4):591-7. 